\title{
EPISTEMOLOGY AND STRATEGY OF MULTICULTURAL ISLAMIC EDUCATION
}

\author{
Ahmad Zarkasyi ${ }^{1}$ \\ zarkazee@gmail.com
}

\begin{abstract}
This article aims to examine the epistemology and strategy of multicultural Islamic education. This research is a case study qualitative research. The data collection method used is documentation. The data were analyzed using the Miles and Huberman model, including data reduction, presentation, and verification. We are checking the validity of the data using source triangulation. The study results indicate that the purpose of carrying out religious education efforts with a multicultural perspective is to create religious understanding for humanists, inclusive, and full of tolerance and mutual respect between adherents of other religions. Thus, from these efforts, harmony and peace will be realized in people's lives by the ideals and essential goals of the universal teachings of religion.
\end{abstract}

Keywords: Epistemology, strategy, Islamic education, multicultural

\begin{abstract}
Abstrak: artikel ini bertujuan untuk mengkaji epistimologi pendidikan islam multikultural. Penelitian ini merupakan penelitian kualitatif studi kasus. Metode pengumpulan data yang digunakan adalah dokumentasi. Data dianalisis menggunakan model Miles dan Huberman yang meliputi reduksi data, penyajian data dan verifikasi. Pengecekan keabsahan data menggunakan triangulasi sumber. Hasil penelitian menunjukkan tujuan dari dilakukannya upaya pendidikan agama yang berawawasan multikultural adalah agar terciptanya pemahaman agama bagi peserta didik yang humanis, inklusif, serta penuh toleransi dan saling menghargai antar pemeluk agama lain. Sehingga, dari upaya tersebut pada akhirnya akan dapat terwujud keharmonisan dan kedamaian di dalam kehidupan bermasyarakat, sesuai dengan cita-cita dan tujuan hakiki dari ajaran agama yang universal.
\end{abstract}

Kata kunci: Epistimologi, Srategi, Pendidikan Islam, Multicultural

\section{Introduction}

Multiculturalism is an understanding that seeks to understand the differences that exist in humans as something natural and make these differences acceptable without causing harmful excesses in the form of discriminatory actions, mutual envy and prejudice. (Thoyib 2020). However, suppose this understanding is not packaged in the realm of education and awareness that is appropriate and proportional. In that case, it is not impossible that this understanding will create a significant enough potential for conflict between individuals or groups.

\footnotetext{
${ }^{1}$ STIS Miftahul Ulum Lumajang
} 
The Sampang incident, for example, is an example of violence and horizontal conflict that has drained much energy and has significantly harmed many parties, not only in terms of soul and material but also has sacrificed the harmony between people in Indonesia. The principle of diversity within each group will easily cause sparks of conflict due to the many differences. (Abdurrahmansyah 2017). So, this is where the importance of multicultural education efforts is to find a meaningful place and, of course, to unify the nation.

Multicultural education is an educational strategy applied to use and manage cultural differences in society regarding ethnicity, religion, language, gender, race, social class, age, and so on into something more potent and more accessible in learning and education. (Tang, Cikusin, and Ghony 2018). Multicultural education also seeks to train and build students' character to have a democratic, humanist, and pluralist attitude in their environment. In this case, education is considered the most effective medium to give birth to a generation with a positive outlook and appreciation of differences.(Fauzi 2018) Mentions, as quoted by Sangkat, that there are at least four main issues that are seen as the normative foundation of multicultural Islamic education, especially in the religious field, namely

1. unity in the aspect of divinity and His role (revelation),

2. unity prophethood,

3. there is no compulsion in religion, and

4. recognition of the existence of other religions.

The basic concept of multicultural education has these four values (core values) (Nugroho 2016), Namely: 1) Appreciation of the reality of cultural plurality in society. 2) Recognition of human dignity and human rights. 3) Development of global community responsibility. 4) Development of human responsibility and towards planet earth.

Based on the core values above, several objectives related to these core values can be formulated. (Asrori 2008): 1) Developing various historical perspectives from community groups. 2) Strengthening cultural awareness that lives in the community. 3) Strengthening intellectual competence and cultures that live in the community. 4) Eradicating racism, sexism, and various types of prejudice (prejudice). 5) Develop awareness of ownership of the planet earth, and develop social action skills.

From the description above, several things need to be studied in applying multicultural Islamic education in Indonesia (Rofi 2018). First, multicultural education has inherently existed since the Indonesian nation existed. The philosophy of the Indonesian nation is Bhinneka Tunggal Ika, tribes work together, help, and respect one another, how can be seen in the chronological portrait of this nation which is full of the entry of various foreign ethnic groups and continues to acculturate with indigenous people.

Second, (Rofi 2018) Multicultural education provides a glimmer of hope in overcoming various societal upheavals recently. Multicultural education is education 
that always upholds values, beliefs, heterogeneity, plurality, and diversity, regardless of its aspects in society.

Third, multicultural education opposes business-oriented education. At this time, educational institutions, both schools and universities, are competing to make their educational institutions an institution that can generate large incomes. Fourth, multicultural education is a resistance to the fanaticism that leads to various types of violence. Violence arises when the channel of peace is no longer there. The violence results from the accumulation of various community problems that are not entirely resolved and mutually accepted. (Thoyib 2020).

The methods that can be applied in religious education with a multicultural perspective are pretty diverse. The best method in learning varies, both between teacher-centred techniques and student-centred learning techniques.

One method that can be applied is to use a "communicative model" by making differences as a pressure point. (Mahsun 2019). This method is very effective, especially in the teaching and learning process, a comparative study of religion and culture. Because, with this communication, every community with a different background can express an opinion in an argumentative manner.

In addition to the above methods, it is also necessary to apply other methods as supporting methods such as active learning methods (collaborative learning), learning methods through self-discovery and experience (self-discovery learning), lectures (Socratic teaching), namely lectures or exposures that begin with questions are then given answers that continue to flow so that there is an interaction between educators and students. (Istiqomah et al. 2020).

In his book "Emoh Sekolah", Ainurrofiq Dawam (2003) Explains that multicultural education is the process of developing all human potentials that respect plurality and heterogeneity due to cultural, ethnic, ethnic and religious diversity. Multicultural education requires the highest respect and appreciation for human dignity, wherever it comes from and any culture. The hope is that true peace can be achieved, security that is not haunted by anxiety and happiness without engineering.

\section{Research Method}

This study uses the descriptive analysis method by collecting data, compiling or clarifying, compiling, and interpreting primary data sources. (Malliari and Togia 2016). This research was conducted by reading, analyzing, and analyzing various literature sources and research results. In this study, researchers used two kinds of data, namely primary data and secondary data. So data collection is determined by reviewing literature and library materials relevant to the problems studied, both from books and data using library materials on the epistemology and strategy of multicultural Islamic education. (Sari and Asmendri 2018). 
The study or analysis method used in analyzing is inductive analysis. Qualitative data analysis is inductive, i.e. analysis based on the data obtained is developed. In inductive analysis, two possibilities will arise in determining the category. (Abbott 2008). The first possibility is that researchers will use categories commonly used by research subjects, and the second possibility is that researchers can use categories developed by themselves. Alternatively, the researcher can combine the two methods, namely, using all the usual categories. If he finds new data outside the ordinary category, the researcher can name the new category himself.

\section{Result and Discussion}

\section{The Epistemological Dimension of Multicultural Islamic Education}

The development of religious education with a multicultural perspective can be applied to several aspects (Latif 2016), namely: content orientation (curriculum), student orientation, and academic unit reform orientation (schools). In contentoriented education, (Elhefni and Wahyudi 2017) Offers a curriculum reform framework with several approaches: first, a contributive approach, where the main objective of this approach is to include materials on the diversity of religious groups (including ethnic groups and community culture).

Second, (Mu'minin 2019) an additive approach, which is adding content, new concepts to the curriculum without changing the basic structure. With this approach, religious education utilizes specific multicultural content as an enrichment of teaching materials, concepts about the harmony of life between religious communities, which will give the nuances to break the frozen state of mind (thoughts) of education actors in responding to the existence of religions - other religions and themes of tolerance, co-existence, pro-existence, cooperation, mutual respect, and understanding. The same thing was also expressed (Mulyono 2019); He stated that the design for implementing multicultural education was based on the following tools: curriculum reform, teaching social justice principles, developing multicultural competencies, and implementing equality education.

The indicator of the success of multicultural education is the formation of humans who can position themselves as humans and have a different identity from other people in society. In addition, he has the ideology of theism (divinity), humanism, socialism and capitalism with the appreciation and experience to be pluralist, heterogeneous and humanist. Therefore, indicators of the success of multicultural education can be seen in determining the ideology developed in the educational institution.

To design a strategy for multicultural relations in education (including religious education), it can be classified into at least 2 (two) experiences. (Rofi 2018), namely: personal experience and teaching experience carried out by teachers (educators). Personal experience can be conditioned by creating an atmosphere: first, 
all students, both minority and majority, have the same status and tasks. Second, all students associate, relate, develop and sustain together. Third, all students relate to the same facilities, teacher learning styles and class norms. The form of teaching experience is as follows: first, the teacher must be aware of the diversity of students. Second, curriculum and teaching materials should reflect diversity. Furthermore third, curriculum materials are written in different regional/ethnic languages.

According to A. Qodry Azizy (Tedi Priatna, Payiz Zawahir Muntaha 2019), the approach taken in multicultural-minded education is a "holistic-integrative" approach, namely an approach that views that: first, education is a continuous process. This means that human needs and interests will never be completed.

Education, in this case, does not stop when humans (students) become adults. However, it will continue to develop in 4 (four) dimensional interactions (Nugroho 2016), namely: humans with themselves, humans with humans, humans with the surrounding environment, and humans. With his God. Second, the educational process means cultivating human existence, and this existence certainly requires interaction with oneself and something outside of oneself.

Third, education seeks to create a human social existence (A M Rosyad 2020). In this sense, the educational process prepares students to become members of the community or live in society, but the educational process forms the community itself. Fourth, the educational process that is entrenched and full of values. Moreover, fifth, the view that social and cultural processes have dimensions of space and time.

\section{Multicultural Islamic Education Strategy in Indonesian Context}

Some of the basic concepts that are the reason that multicultural education is a necessity (objective must) in PBM in the classroom are: First, cultural diversity can be an independent variable that has a very significant contribution to the success of the curriculum both as a process and learning outcome (Bahri 2020). Therefore, the multicultural condition should be a factor to be considered in determining the philosophy, theory, vision of education and curriculum, as well as the learning process of each subject in the classroom. The historical reality proves that every process of human empowerment in the life of a group (society or nation) that does not pay attention to the multicultural objective conditions of group members is a trigger or cause for conflict to occur so that the group's goals cannot be adequately achieved.

Second, the nature of life always appears in diversity (multicultural); therefore, building an educated, cooperative mental attitude and understanding the pluralist reality of life is very important to minimize conflict and group disintegration (Abdurrahmansyah 2017). When the nation's children cannot build an attitude of multiculturalism, the portrait of group life will be coloured by the attitude of imposing their ambitions and interests (Kurniyati 2020). Therefore, an educator must be able to instil the core values of multicultural education, namely democracy, humanism, and 
pluralism, both through a theoretical approach (scientific concepts) integrated into the subjects taught and through a practical approach (exemplary) every day at school.

The teacher's role in shaping students' character in terms of multicultural sense is very central (Muliadi 1970). When multicultural values (democracy, humanism, pluralism) are internalized (institutionalized or have been patterned) in a child, the child will easily make positive, innovative, dynamic and tolerant behaviour changes, and 'in fact, this is the core or mission of education or learning'.

Third, the learning theory used in the future multicultural education approach should not only be based on learning psychology theory that is individualistic and places students in a value-free condition but must also be based on learning theory that places students as socio-cultural beings and dynamic, innovative politics with distinguished personalities rooted in religious values and a pluralistic nation's culture (Thoyib 2020). Therefore, teachers have a central role in shaping students' character in instilling values and attitudes towards anti-discrimination of race, ethnicity, religion, gender, abilities and groups in any form in their environment (Thoyib 2020). Modern life today presents a competitor's lifestyle in all aspects with the movement of change so fast; this requires the mental attitude of the nation's children who are superior, innovative, tolerant, democratic and humanist. Only through the door of education and learning that is well designed will produce a multicultural mental attitude of the nation's children.

Fourth, the challenges of life in the era of information technology (IT) transformation and the current era of globalization require the formation of a mental attitude of the nation's children who can build attitudes: leader principle, vision principle, and well organize principle, in order to be able to compete in various fields of life both in the local realm (Istiqomah et al. 2020). In this case, the teacher has a very strategic position in building these three principles through an integrated multicultural education learning process in every subject. Each subject can essentially be developed by incorporating multicultural concepts.

Several strategic steps that can be taken by teachers in implementing multicultural education in PBM in the classroom include (Tang, Cikusin, and Ghony 2018): (1) every teacher should have an attitude of understanding and comprehensive insight about anti-discrimination attitudes in various aspects at school; (2) every teacher must have a strong sensitivity to the symptoms of multi-aspect discrimination, no matter how small it takes place in the classroom. When symptoms of discrimination: race, ethnicity, gender, ability appear, the teacher immediately takes strategic-educative action; (3) every teacher must be a direct example through attitudes and behaviour regarding the application of democratization, humanization and pluralization during the learning process in the classroom; (4) each teacher has a periodic schedule every semester to give individual assignments to students about the 'theme of the importance of multiculturalism' in the life of Indonesian people; (5) each teacher during the learning process inserts one or two problems (problems) for 
students to answer related to multicultural values; and (6) each teacher encourages the institution (teaching place) to hold dialogues about multiculturalism or studies of multiculturalism periodically.

Meanwhile, relating to aspects of the future development of the IQF based on a multicultural approach, this can be done in the following steps (Istiqomah et al. 2020): First, the philosophy of the curriculum must be oriented to a philosophy that is more in line with the goals, missions, and functions of each level of education and education unit services. The direction of the curriculum philosophy should develop aspects of education to develop the humanist, democratic and pluralist abilities of students, both as individuals and citizens of the nation.

Second, curriculum theory about the content (curriculum content) must change from a theory that defines content as a substantive aspect that contains facts, theories, generalizations to an understanding that includes 'values, morals, procedures, processes, and skills that students must possess at school. Globalism globalization (Ali Miftakhu Rosyad 2019); Third, the learning approach in future classes must pay attention to the diversity (multicultural) of students' abilities, social, cultural, and economic and should no longer be based solely on individualistic learning psychology theory and place students in a value-free condition, but must also be based on a learning theory that places students as social, cultural, political, active-creative, and cooperative beings in the plurality of Indonesian and world society; and Fourth; The evaluation used must cover all aspects of the abilities and personality of students, by the objectives and content developed. The evaluation tools used must be diverse and integral (regarding performance; affective; paper and pencil tests; portfolio; and selfassessment) according to the nature of the objectives and the information to be collected (BSNP, 2006).

\section{Conclusion}

The analytical descriptive description above provides a basic understanding of the importance of integrated multicultural education in learning each subject in the classroom. The urgency of multicultural education for these students can be seen from the aspects: The objective reality of very pluralistic students; The objective conditions of the Indonesian society's very diverse socio-cultural life; and The demands of future life in the era of globalization that require dynamic, innovative, democratic and humanist mental attitudes amid the world's cultural diversity. A teacher in the classroom who has a strategic position in learning is required to have professional abilities in empowering the diversity of students towards excellence in educational outcomes. When the teacher can play a role in colouring democratic, humanist and pluralist mental attitudes in each student, the teacher is a 'hero without merit'.

On the other hand, PAI textbooks are still full of doctrines from certain opinions (schools) by only discussing the study of the opinions of scholars who are 
considered to represent the understanding of certain majorities in Indonesia, even though Indonesia is a pluralistic country and of course this in the concept of multicultural education is a form of doctrine. Even discrimination against minorities. Furthermore, the new PAI material is explicitly integrated into the concept of multicultural education, and this can be seen from the various discussions that are not so clear and sometimes partial. So that textbooks still look exclusive, especially those related to theology (belief issues). Overall, textbooks have not directed students to have an inclusive mindset because textbooks only convey material on religious education (especially Islam) only at the normative level and very little concerning meaning.

\section{REFERENCES}

Abbott, Andrew. (2008). "Library Research and Its Infrastructure in the Twentieth Century Windsor Lecture University of Illinois," 1-27.

Abdurrahmansyah, Abdurrahmansyah. (2017). "Pendidikan Multikultural Dalam Desain Kurikulum Dan Pembelajaran Keagamaan Islam." Madania: Jurnal Kajian Keislaman 21 (1): 79. https:/ / doi.org/10.29300/madania.v21i1.251.

Asrori, Mohammad. (2008). “Dinamika Pendidikan Islam.” El-HARAKAH 10 (1): 1-197.

Bahri, Saiful. (2020). "Multicultural Education In Islamic Education Philosophy Perspective." Istawa : Jurnal Pendidikan Islam 5 (2): 239. https://doi.org/10.24269/ijpi.v5i2.2891.

Elhefni, Elhefni, and Apri Wahyudi. (2017). "Strategi Pengembangan Pendidikan Multikultural Di Indonesia." Elementary: Jurnal Ilmiah Pendidikan Dasar 3 (1): 53. https://doi.org/10.32332/elementary.v3i1.800.

Fauzi, Ahmad. (2018). "Paradigma Pendidikan Islam Multikultural Di Era Melenial; Sebuah Kajian Diskurtif." Edureligia; Jurnal Pendidikan Agama Islam 2 (1): 1-10. https://doi.org/10.33650/edureligia.v2i1.752.

Istiqomah, Nur Asih, Migfar Rivadah, Mohamad Nizar Potabuga, and Arif Rahman. (2020). "Strategi Dan Peluang Pembelajaran Pai Berbasis Multikultural," 291301.

Kurniyati, Ety. (2020). "East African Scholars Journal of Education, Humanities and Literature The Urgency of Multicultural Education to Islamic Learning in Schools" 7250: 162-68. https:// doi.org/10.36349/EASJEHL.2020.v03i05.022.

Latif, Muhaemin. (2016). “MULTICULTURAL EDUCATION IN ISLAMIC BOARDING SCHOOL (A Descriptive Study of Pesantren DDI Mangkoso, South Sulawesi) Muhaemin." Journal JICSA 05 (02).

Mahsun, Murzal. (2019). “Nilai Multikultural Dalam Pembelajaran Pendidikan Agama Islam (PAI) Di Sekolah: Studi Terhadap Upaya Membina Karakter Siswa Di SMKN 1 Gerung." Jurnal Penelitian Keislaman 15 (1): 66-83. https://doi.org/10.20414/jpk.v15i1.1103. 
Malliari, A, and A Togia. (2016). "An Analysis of Research Strategies of Articles Published in Library Science Journals: The Example of Library and Information Science Research." Qualitative and Quantitative Methods in Libraries (QQML) 5: 805-18.

Mu'minin, Amirul. (2019). “Konsep Dasar Epistemologi Pendidikan Multikultural Dalam Islam Zainun." Jurnal At-Tarbiyat : Pendidikan Islam 1 (2). https://doi.org/10.30649/fisheries.v1i2.23.

Muliadi, Erlan. (1970). “Urgensi Pembelajaran Pendidikan Agama Islam Berbasis Multikultural Di Sekolah." Jurnal Pendidikan Islam 1 (1): 55. https://doi.org/10.14421/jpi.2011.11.55-68.

Mulyono, Mulyono. (2019). "Pembelajaran Pendidikan Agama Islam Berbasis Multikultural." $\quad$ El-Wasathiya $\quad 7 \quad 18$ : https://core.ac.uk/download/pdf/266978017.pdf.

Nugroho, Muhammad Aji. (2016). "Pendidikan Islam Berwawasan Multikultural; Sebuah Upaya Membangun Pemahaman Keberagamaan Inklusif Pada Umat Muslim." MUDARRISA: Jurnal Kajian Pendidikan Islam 8 (1): 31-60. https://doi.org/10.18326/mdr.v8i1.31-60.

Rofi, Zaenuri. (2018). “The Implementation of Islamic Education in Shaping Tolerant Characters in Multicultural Perspective." Attarbiyah: Journal of Islamic Culture and Education 3 (1): 86-108. https:/ / doi.org/10.18326/attarbiyah.v3i1.86-108.

Rosyad, A M. (2020). "The Integration of Islamic Education and Multicultural Education in Indonesia." Al-Afkar, Journal For Islamic Studies 3 (1): 164-81. https://al-afkar.com/index.php/Afkar_Journal/article/view/87.

Rosyad, Ali Miftakhu. (2019). "Implementasi Nilai-Nilai Multikulturalisme Melalui Pembelajaran Pendidikan Agama Islam." Risalah: Jurnal Pendidikan Dan Studi Islam 5 (1): 1-18. https:/ / doi.org/10.5281/zenodo.3550530.

Sari, Milya, and Asmendri. (2018). “Metode Penelitian Kepustakaan (Library Research)." Penelitian Kepustakaan (Library Research) Dalam Penelitian Pendidikan IPA 2215. https://ejournal.uinib.ac.id/jurnal/index.php/naturalscience/article/view/15 $55 / 1159$.

Tang, Muhammad, Yaqub Cikusin, and Djunaedy Ghony. 2018. "The Value Orientation of Multicultural Islamic Education in the Sipakatau Culture." International Journal on Advanced Science, Education, and Religion 1 (3): 17-29. https://doi.org/10.33648/ijoaser.v1i3.17.

Tedi Priatna, Payiz Zawahir Muntaha, Nurhamzah. (2019). “Vision of Multicultural Islamic Education Paradigm in Indonesia." American Journal of Humanities and Social Sciences Research (AJHSSR), no. November.

Thoyib, Muhammad. (2020). “The Management of Multicultural Resolution on PostTransnationalism of Indonesian Islamic Education: Challenges for the Future." Cendekia: Jurnal Kependidikan Dan Kemasyarakatan 18 (2): 231-47. https://doi.org/10.21154/cendekia.v18i2.1901. 